\title{
Film Poetry: the Theoretical Institution and Development in the Early Film Theories
}

\author{
Juanjuan Bai \\ School of Literature, Nanjing University \\ School of Media, Linyi University \\ Nanjing, China \\ e-mail: toruno@163.com.cn
}

\begin{abstract}
The poetry is an important aspect of the film creating, also an important inflection of the value of art. In the early stage of the film, the problem of the poetry had been an especially important topic among the film theorists. A great many theorists had participated in the process of exploring the poetry of the film, and analyzed it from different aspects, which mainly included the Avant-garde of France, Bella Braze the Hungarian film theorist and the formalism genre from Russia.
\end{abstract}

Keywords-film; poetry; film theory

\section{INTRODUCTION}

Poetry is always a common but important conception in theory researching and practicing of film, because as embody of the beauty of art, the poetry is an important aspect of the film creating, also an important inflection of the value of art.

At the end of nineteenth Century to early twentieth Century, so as to the very early years when film was just born, it was universally considered as some vulgar juggle or naive imitation to the theater arts instead of an independent art. However, poetry belonged to the category of artistic expressing, so only when the film became a kind of art, could the poetry be appeared in it. In another word, that the poetry was came into being with the process of the film becoming a kind of art. So, in the early stage of the film, the problem of the poetry had been an especially important topic among the film theorists, because the poetry was one of the important characters of the art, also an important standard which decided whether the film was one of the kind of art. For such reasons, exploring the poetry in the film as well as its artistic techniques of the expression had a significant meaning on the institution of the artistic status of film consequently. As a result, a great many theorists had participated in the process of exploring the poetry of the film, and analyzed it from different aspects, which mainly included the Avant-garde of France, Bella Braze the Hungarian film theorist and the formalism genre from Russia.

\section{II. “The Visual PoeT” AND The Poetic Film Proposition OF THE AVANT-GARDE GENRE}

As a film movement, the Avant-garde genre was about raised in the year of 1918, and finished in the late 1920s', which had Ricciotto Canudo, René Clair, Louis Delluc, Jean Epstein and some other members and was the first film genre to claim the proposition of "the poetic film". Compared with other film theorists in the same period, an important character of the Avant-garde was that the film practicing and theory researching were both generous to them. Most of the members in the Avant-garde were both theorists and film directors, so this kind of close combination between the theory and practice of film decided that the Avant-garde's research and exploration about the poetic film was established on the basis of the noumenon of the film, which signified they caught hold of the visual essence of film. Ricciotto Canudo had claimed that the film was firstly a kind of visual image that represents the essence of life [1]. However the premise of visuality was the internal emotion and mental status of people. Henri Agel the French film theorist considered that Canudo earlier than most of the modern audience had seen the highest purpose of the film from its intrinsic performance rather than its appearance [2], and the highest purpose was just about the poetry that the Avant-garde pursuits_ - the spiritual attribute of the film. This was also the core theory of the Avant-garde that they had not stopped on arguing whether the film had some kind of poetry or not, but began to explore how the poetry was produced and expressed from the visual essence of the film. Their focus was how the film could reappearance the heart, express the emotion and reflect the poetic status by its unique form.

The Avant-garde considered that the poetry came from the visual essence of film. Canudo claimed the proposition of "Photogenie" which was developed by Delluc and Epstein, then became one of the core propositions of the Avant-garde. Agel considered that the word referred to such poetic status which was appropriate for the film the newly media to express by its unique performance method [3]. Delluc considered that the word of "Photogenie" did not mean that someone was beautiful and was suitable to appear on the screen, but mean that by the shooting of the camera and with the effect of the light, background and some other visual elements, the people or objects were added some special expression, acquired some spirit beyond the physical reality, and then expressed people's soul and the essence of the world. He especially emphasized that the word expression (génie) had an important meaning to the"Photogenie". It was 
because that the visual essence of the film endowed some kind of expression to the screen, could the film get rid of the mechanical reproduction to the physical world and go up to become a kind of absolutely spiritual art, and perform its unique poetic character. In another aspect, Epstein considered that the "Photogenie" was a kind of stirring and potential power. It was all of the things, living beings, mind, and all of the phenomena which were increased in their spiritual characters by reappearing in film [4]. In a word, both Dolluc and Epstein opposed such accurate photography prevalently in that time, claimed that the nature and plain technique which could extrude the spiritual character of the film. In fact, "Photogenie" was the concentrated reflection of the spiritual character of the film, and the important esthetic character which manifested its inner verve and poetry by using its photographical appearance. So it was obvious that the basis of "Photogenie" was the visual essence of the film, also we can say that the basis of poetry was the visual essence of the film. Aristarco the film theorist of Italy considered that the word "Photogenie" invented by Canudo referred to the character of the film and the value of the essence of the film. It was because that the poetry came from the visual essence of the film, then it could be proved to be the essential character of the film.

In the concrete expressional forms of the film poetry, the Avant-garde from the visual essence of the film opposed the simple copy to theatre and such profit theatrical film, claimed that the film should simplify its plot even cancel the plot so as to focusing on weaving the emotions and feelings for the sake of reaching the greatest freedom of the mental associating. Germain Dulac the French film director, also an important member of the Avant-garde had said that it could narrate in the film, but did not forget that story was absence of the value, which was just a surface. The film should acquire its inflectional elements from the unique visual pictures [5]. The Avant-garde considered that the expressive object of the film should be the light, movement, line, rhythm and some other pure visual elements. The film should use such elements to weave the emotion, creating the poetry, which was not only the fundamental character that distinguished the reality and the art, by also an important standard that distinguished the theatre and the film, furthermore an inherent meaning of the "Photogenie". For this reason, the Avant-garde claimed the conception of "pure film". With this conception, they tried to get rid of the narration in the film by using the pure visual elements such as the light, line, movement and rhythm to create some kind of poetry as well as infecting the audience. Andre Bokely another member of the Avant-garde despised the narration of the film. He believed that the value of such narrative films was not higher than the pamphlets that usually read in the kitchen and the novels that usually circulated in the bookstalls and the underground passages [6]. The others members of the Avant-garde also did not approve the value of the film narration, they thought that the films which narrated like the novels was just some kind of simple and crude form, which was simply descriptive, however the visual rhythm had the power of weaving the feelings and was available to create great emotions. The rhythm not only reflected in the midst of the frames, but also reflected between the frames by connecting them, furthermore, the connecting and editing of film could not only create the rhythms, but also could give expression to the poetry. So the Avant-garde claimed that the most consummate form for the film was the "film poet", where the visual image reached the purest and the highest intensity, and where this kind of "film poet" would generalize all of the images [7].

Simply plot or canceling plot, this conception at that time undoubtedly had an avant-courier meaning, which made the film get rid of the restriction of imitating the theatre, therefore acquired the possibility of expressing feelings, emotions and reflecting the poetry. Under the conception of cancel plot, the Avant-garde explored the artistic expression to the visual essence of the film in multiple aspects, and on the basis of the visual essence, they promoted the film poetry to the height of the essential properties of the film, which had a great meaning on the exploration of the poetic characters of the film. The poetic reality film which rose in France in the 1930s emphasized on compositing the pictures and creating lyrical atmosphere. It was obviously effected by the Avantgarde.

In the history of the film, the Avant-garde was the first film genre to claim the slogan of "poetic film" as their theoretical guiding principle. Jean Epstein, one of the representative member of the Avant-garde had once said that the film was the most powerful technique for expressing the poetry, which was the most realistic method to express the most unrealistic things. And this was the real reason for our few persons to give our great expectation to it [8]. This indicated that the film poetry had been an important component in their theatrical system, the core which penetrated in their theatrical and practical explore, and the soul of the conceptions including the "photogenie", the "pure film" and the "film poet". However, in another aspect, the Avant-garde had been considered as the formalism with the reason of claiming simple plot. They suffered the criticism of excessively despising the theme and paying attention to the form of the film. Human was the center of the artistic expression, which decided the essence of the art, so decided the essential meaning of the poetry. The ideal poetry was established on the basis of people, which was the sublimation of the people's feeling, the aesthetic annotation to the people's living condition. So denying the plot signified that they neglected the subjective status of people in the film, as well as the life meaning of the poetry. On the view of the Avant-garde, all of the spirits and feelings beyond the physical reality could be affirmed to be the poetry. The Russian film theorist Dobin thought the circumscribed point of the Avant-garde was just that they had not seek the feeling and emotion from the scenes containing people, but from the nature, the invisible and intangible things, and the abstractive movements [9]. That was one of the reasons why the Avantgarde was considered as the formalism.

\section{III. “THE VISIBLE PEOPLE” AND THE POETIC FILM PROPOSITION OF BÉLA BALÁZS}

In the year of 1924, the film theorist and reviewer Béla Balázs from Hungary published his book writing named the Visible People. He claimed delightedly in that book: now, 
the film would break a new direction in our cultural field. ......people had already learned and mastered the rich and colorful language of gesture, movement and face expression. This was not a kind of sign language or symbol language that could replace the spoken language, but a tool which was visible and could express our soul inside our sensual bodies, so everything was becoming visible once again [10]. Here revealed two points of view. Firstly, by the original and unique expressional techniques such as the close-up shot, the film could express the countenance and gestures of people, then revealed the feeling and soul of people, which revealed the poetry character of the film. Balázs considered that the invention of the film helped to bring about the birth of a kind of new artistic expressional form. The visual and intuitive characters had liberated people from the constraint of the letter symbols, and by the unique expressional technique it could reveal the soul of people. For the intrinsic vitality of the film was expressed by the extrinsic countenance, so from the countenance, we could penetrate the secret heart of people. Balázs investigated the film in multiple aspects about its unique technique for expressing the countenance, then pointed out that the film was not the narratives, but the lyrics, because the lyric plentiful and changeable expressional technique belong to the countenance had unparalleled superiorities when compared with all kinds of the other literature styles [11]. On the other hand, Balázs deemed that all of the things in the film was symbolic. Not only the persons, the stage properties and the other of the real subjects, but also the light, the position and the scale had reveal some kinds of the figurative meanings, which made the film exceeded the perceptual intuition about the objective reality, and then acquired a more profound meaning: the expressive force to the spiritual world of people. This kind of metaphor and symbol made the film turned into the lyrical poet.

The other contribution of Balázs to the early film theory was he established the conception that people were the center of the film expression. The center of any kind of the arts were inevitably the human, and the film as an art, its expressional center was also inevitably the human. By showing the faces and gestures, the ultimate thing we could see was people and their soul. In Braz's opinion, the real reason for the film to become a kind of art was because it could artistically express the human-centered world.

Compared with the Avant-garde, Balázs' theory highlighted the importance of people in the film, explained how people and their emotions as the center of the artistic expression were showed by the visual essence of the film, and therefore expressed the lyrical poetry. In his opinion, the film could deliver the poetry just because it could express people's emotion and soul. Balázs made clearly that people was the center in the poetic expression. This was the amendment and supplement to the theory of the Avant-garde, also an important theoretical progress to the poetry theory. However, although Balázs had noticed the similarity in the aspects of the metaphor and symbol between the film and the poet, he had not researched the problem farther to compare the differences between the film language and the poet language and explain the linguistic principles. The task was accomplished by the formalists in the same period.

\section{THE FILM POETICS AND THE RUSSIAN FORMALISTS}

The Russian formalism language school who rose around the 1920s originated from the Moscow linguistics society and the poetic language research society in Petersburg. From the name, it was easy to know that the central content was the relationships between the language and the literature as well as the poet. In the year of 1914, Viktor Shklovsky published a pamphlet named The Resurrection of words, in which he announced that the artists should resurrect the vitality of the words just like to restore the brilliance of the antique diamond. It was just like a powerful declaration which declared an important transformation in the western literary theory in the 20th century that was from the sociological and psychological researching method to the linguistic and work-centered method. The formalists dissatisfied the sociological and philosophic methodology which occupied the dominant positon in the Russian literary criticism, at the same time opposed analyzing works only from the author's biography and his or her background. They claimed to establish a new theoretical proposition which was work-centered and analyzed the works as well as expounded the artistic principles from the angle of language. So the formalists was considered as the first poetic system who was work-centered in the history of the literary theory. They expounded their theory to different kinds of arts, including the film who was still wandering around the door of the art at that time. They researched the film from the linguistic method, analyzed the film from the angle of language, rhythm, and figure, and explained the reasons why the film was a kind of art. In the year of 1927, the formalists published a book named the film poetics, which was considered as the first book that grasped the essence of the film from the angle of the theory.

From the angle of comparing the differences between the daily language and the poetic language, the formalists proved that the film was a kind of art. Boris Mihailovich Eihenbaum, one of the main members of the formalists considered that the relationship between the photography and the film was just like the relationship between the daily language and the poetic language. The film camera could find and utilize some effects that the common camera could not use [12]. This was the reason that why the film could be a kind of art however the photograph still could not, although it had already began the process toward it. Because the photograph was static so it could only have the reproducibility and had not any effects of the rhetoric, however the film could keep the static pictures moving and let the mechanical method of the photograph transforming into the special film language, so it could be a kind of art.

In Eihenbaum's opinion, the film could utilize its special characteristics such as the changing of the lights, the shadow, and the shooting angle to form the rhetoric effects, which was the reason why it could go beyond the photograph and become the art that was nearest to the poet. In that way, how could the daily language become the poetic language, then create the rhetoric effects? For this question, Eihenbaum 
borrowed the conception of "photogenie" from the Avantgarde. The Avant-garde considered that the poetry came from the "photogenie" which could produce special expression and spirit, but they had not explained more deeply about where the poetry came from and how it was produced by the changing of the light and the shooting angles. Eihenbaum affirmed the validity of the "photogenie", then explained the origin and the linguistic principle of it. $\mathrm{He}$ claimed that the essence of the art was game, which was reflected in those unreasonable and itself-purpose impulsions. These impulsions opened various kinds of arts, and was their organic enzymes. By using the enzymes and transforming them into the performance ability, the art as a social a kind of phenomenon and a special language was then formed [13]. There was always contradiction between the unreasonableness of the art and the form of the language, however just the existence of the contradiction restricted the development of the art, and this was just the problem of the form in the art. The "photogenie" was the unreasonableness of the film, which reflected in the intangible and mysterious spiritual feelings and could only be expressed by the special language of the film. So how to reflect the unreasonableness by the method of the form of the film? Eihenbaum said that as a kind of expressive ability, the photogenie transformed into the facial expression, gesture, image, shooting angle, scene and some other language forms, and all of those forms constituted the basis of the film rhetoric. In this way, Eihenbaum had found the relationship between the artistic characteristics of the film and its language forms. It was by the rhetoric the daily language could be transformed into the artistic language, then acquired the spiritual character and poetry. Whereupon, the formalists had explained where the intangible and mysterious spiritual elements originated by the angle of linguistics, in other word, they told where the mysterious elements increased by the shooting of the camera came from. The conclusion was that the poetry came from the film rhetoric, namely the metaphor and symbol. By the rhetoric, the film language transformed from the daily language to the poetic language and expressed the poetry. By using this method, the formalists recognized the conception of "photogenie" as the essential character of the film, explained the origin of the poetry, and therefore laid the foundation for the film poetics.

The early film theories including those theories and conceptions from the Avant-garde, Béla Balázs, and the formalists set up the prime structure for the poetic theory of the film, and affected the film practice in that time and the afterwards, which mainly included the French poetic realism film in the 1930s and the Russian poetic film in the 1950s. After the Russian poetic film, such filmic movements or theatrical trends which concentrated on exploration for the filmic poetry had not appeared again, but the research and discussion had not stopped yet. In fact, after the 1960s, the explosion to the film poetry presented on a way of dispersion worldwide. The poetic films from Federico Fellini, Theo Angelopoulos, Abbas Kiarostami, Yasujiro Ozu and some other directors enriched the artistic expressive ability of the film, promoted the artistic character, and guided a unique aesthetic trend in the modern film when it was growing more and more commercialized.

\section{REFERENCES}

[1] Canudo R, Film is not theater, Li Hengii, Yang Yuanying, Selected works of foreign film theory, SDX Joint Publishing Company, Beijing, 2006, vol. 1, pp. 57.

[2] Agel H, Film aesthetics, China Film Press, Beijing, 1994, pp.5.

[3] Agel H, Film aesthetics, China Film Press, Beijing, 1994, pp.6.

[4] Epstein J, The Essence of Film, Li Hengji, Yang Yuanying, Selected works of foreign film theory, SDX Joint Publishing Company, Beijing, 2006, vol. 1, pp. 83, 92.

[5] Dulac G, Film-the Visual Art, Li Hengji, Yang Yuanying, Selected works of foreign film theory, SDX Joint Publishing Company, Beijing, 2006, vol. 1, pp. 93, 92.

[6] Dobin, Film Atistic Poetics, China Film Press, Beijing, 1984, pp.17.

[7] Dobin, Film Atistic Poetics, China Film Press, Beijing, 1984, pp.18.

[8] Epstein J, The Essence of Film, Li Hengji, Yang Yuanying, Selected works of foreign film theory, SDX Joint Publishing Company, Beijing, 2006, vol. 1, pp. 88

[9] Dobin, Film Atistic Poetics, China Film Press, Beijing, 1984, pp.19.

[10] Balázs B, Visible People, Li Hengji, Yang Yuanying, Selected works of foreign film theory, SDX Joint Publishing Company, Beijing, 2006, vol. 1, pp. 31.

[11] Balázs B, Visible People, the Spirit of the Film, China Film Press, Beijing, 2003, pp.40,41.

[12] Eihenbaum M, The Film Rhetoric, Li Hengji, Yang Yuanying, Selected works of foreign film theory, SDX Joint Publishing Company, Beijing, 2006, vol. 1, pp. 101.

[13] Eihenbaum M, The Film Rhetoric, Li Hengii, Yang Yuanying, Selected works of foreign film theory, SDX Joint Publishing Company, Beijing, 2006, vol. 1, pp. 102. 